\title{
KADAR SERUM GLUTAMATE PIRUVAT TRANSAMINASE PECANDU MINUMAN KERAS DI BANJAR AMBENGAN DESA SAYAN UBUD GIANYAR
}

\author{
IGA Tari Diva Pradnya Dewi ${ }^{1}$, Nyoman Mastra ${ }^{2}$, I Wayan Merta ${ }^{3}$
}

\begin{abstract}
Background Banjar Ambengan is one banjar contained in Sayan village, where people still have the habit of gathering accompanied by excessive alcohol consumption. Consumption of alcohol has a direct relationship with the death cases caused by liver sirosis. The liver mechanism disturbance leads to the case of swelling as the result of the rise of serum glutamate piruvat transminase (SPGT) enzyme.

Objective This study is aimed at investigating the SPGT level of the serum of the alcoholic. The study uses the non-probability sampling technique called snowball sampling. The samples of this study are thirty alcoholic men aging upper eighteen. The respondents will be interviewed to get the deeper information. The research reveals that 6 respondents have high SPGT level (20\%) and 24 of them have normal SPGT level (80\%).

Result of the examination serum SGPT levels alcoholics in the study ranged from 11 to 79.20 $U / L$. The measurement results SGPT levels are high on the research respondents based on the characteristics of age at most 33.3\%, based on the frequency of consumption of at most $33.3 \%$, based on the period of consumption at most 50\%, based on the volume of consumption at most $66.7 \%$, based on the type of liquor consumed at most $66.7 \%$, and based on the type of work at most $50 \%$.

Conclusion SGPT levels of the alcoholics in Banjar sub district Ambengan Desa Sayan Ubud Gianyar regency that of 30 respondents, 20\% respondents had a high ALT levels as many as 6 people and $80 \%$ respondents choose a normal ALT levels as many as 24 people.
\end{abstract}

Keywords: Liquor, Liver, Addict, SGPT Levels

\section{PENDAHULUAN}

Hati adalah organ terbesar dan secara metabolisme paling kompleks di dalam tubuh. Organ hati terlibat dalam metabolisme zat makanan serta sebagian besar obat dan toksikan. Hati merupakan organ tubuh yang penting untuk mendetoksifikasi zat kimia yang tidak berguna/merugikan tubuh. Terdapat banyak faktor yang mempengaruhi kerusakan hati, seperti misalnya virus, bakteri, toksisitas dari obat-obatan dan bahan kimia serta konsumsi alkohol yang berlebihan ${ }^{1}$

$$
\text { Minuman keras beralkohol }
$$

merupakan faktor penyebab dari sekitar 60 jenis penyakit dan merupakan faktor komponen dari 200 jenis penyakit lainnya.

\footnotetext{
1.,2.,3., Jurusan Analis Kesehatan Poltekkes Denpasar Korespondensi : Ni Wayan Nia Ariska Purwanti ${ }^{1}$, Jurusan Analis Kesehatan, Poltekes Denpasar, Jalan Sanitasi No. 1 Sidakarya, Denpasar-Bali 80224, Indonesia.

Telp. +62-361-710 527, Fax. +62-361-710448

Email : meditoryjournal@gmail.com
} 
Terdapat berbagai jenis penyakit yang disebabkan oleh konsumsi alkohol, salah satunya adalah gangguan fungsi hati seperti penyakit hati alkoholik (alcoholic liver disease). ${ }^{2}$. Terdapat hubungan langsung antara konsumsi minuman keras beralkohol dengan mortalitas akibat sirosis hati. Gangguan mekanisme di hati dapat mengakibatkan terjadinya pembengkakan dengan adanya kenaikan enzim transaminase yang diproduksi oleh hati ${ }^{3}$. Pemeriksaan yang digunakan untuk mengetahui adanya kenaikan enzim transaminase yaitu dengan melakukan pemeriksaan serum glutamate piruvat transaminase (SGPT) atau serum glutamate oksaloasetat transaminase (SGOT), tetapi pemeriksaan serum glutamate piruvat transaminase (SGPT) lebih spesifik dilakukan karena lebih banyak diproduksi di hati dari pada enzim serum glutamate oksaloasetat transaminase (SGOT). ${ }^{4}$. Penelitian menyebutkan bahwa tingkat kerusakan hati biasanya dapat dilihat dari adanya peningkatan rasio serum glutamate piruvat transaminase (SGPT) lebih dari dua kali angka normal 5. Penelitian lain menyebutkan dampak negatif dari penyalahgunaan minum minuman keras antara lain prestasi sekolah merosot 96\%, hubungan keluarga memburuk 93\%, perkelahian dan tindak kekerasan 65,3\% dan kecelakaan lalu lintas $58,7 \%{ }^{6}$
Pada tahun 2012, seorang laki-laki berusia 57 tahun asal Karangasem mengeluh perutnya membesar disertai dengan nyeri pada ulu hati. Selain itu masih banyak keluhan lainnya yang dialami, setelah dilakukan pemeriksaan untuk diagnosis pasien, ditemukan adanya peningkatan pada bilirubin total, bilirubin direk, bilirubin indirek, serum glutamate piruvat transaminase (SGPT), serum glutamate oksaloasetat transaminase (SGOT), BUN dan kreatinin, albumin rendah, pemeriksaan HBsAg dan anti HCV hasilnya non reaktif. Pasien dikatakan menderita sirosis hati yang disebabkan oleh alkohol. Hal ini semakin diperkuat dengan pengakuan pasien yang gemar mengkonsumsi minuman keras sejak masih muda ${ }^{7}$.

Berdasarkan pengamatan Desa Sayan terdiri dari 8 banjar dan tempat penjualan minuman keras yang masih beroperasi dengan bebas, salah satunya terdapat di Banjar Ambengan. Serta merupakan salah satu banjar dengan jumlah penduduk terkecil yang terdapat di Desa Sayan. Walaupun demikian jumlah pecandu yang terdapat di Banjar Ambengan dapat dikatakan sangat banyak. Dilihat dari kebiasaan masyarakatnya yang masih suka berkumpul dan mengobrol disertai dengan konsumsi minuman keras membuat tempat penjualannya juga semakin banyak berkembang. Bahkan saat ini di Banjar 
Ambengan terdapat dua tempat penjualan minuman keras yang beroperasi secara aktif dan hampir setiap hari selalu ramai dikunjungi oleh masyarakat Banjar Ambengan sendiri.

\section{METODE}

Jenis penelitian yang digunakan adalah deskriptif yaitu penelitian yang dilakukan dengan tujuan untuk mendeskripsikan atau menggambarkan suatu fenomena (termasuk kesehatan) yang terjadi di dalam masyarakat tanpa melakukan rancangan ${ }^{8}$. Lokasi penelitian di Banjar Ambengan, Desa Sayan, Kecamatan Ubud, Kabupaten Gianyar. Pengukuran kadar SGPT dilakukan di laboratorium Rumah Sakit Umum Pusat Sanglah Denpasar. Populasi penelitian adalah keseluruhan dari obyek yang diteliti, dengan menggunakan teknik-teknik tertentu sehingga sampel sedapat mungkin mewakili populasi ${ }^{8}$. Populasi dalam penelitian ini adalah seluruh laki-laki berusia 18 tahun keatas pecandu minuman keras di Banjar Ambengan, Desa Sayan, Kecamatan Ubud, Kabupaten Gianyar sebanyak 48 orang. Unit analisis pada penelitian ini adalah kadar serum glutamate piruvat transaminase (SGPT). 2Responden dalam penelitian ini adalah para pecandu minuman keras di Banjar Ambengan, Desa Sayan, Kecamatan Ubud, Kabupaten Gianyar. Ketentuan responden yang digunakan dalam penelitian ini adalah yang memenuhi kriteria inklusi dan eksklusi. Sampel yang layak dalam suatu penelitian antara 30 sampai dengan $500^{9}$. Dalam penelitian ini menggunakan ukuran sampel minimal yaitu 30 sampel yang mewakili keseluruhan populasi, hal ini dipengaruhi oleh adanya kendala yang dialami peneliti dari segi biaya dan waktu. Teknik sampling dalam penelitian ini dilakukan dengan teknik Nonprobability Sampling yaitu Snowball sampling. Teknik penentuan sampel yang mula-mula jumlahnya kecil, kemudian membesar. Pertama-tama dipilih satu atau dua orang, tetapi karena dengan dua orang ini belum merasa lengkap terhadap data yang diberikan, maka peneliti mencari orang lain yang dipandang lebih tahu dan dapat melengkapi data yang diberikan oleh dua orang sebelumnya. Begitu seterusnya sehingga jumlah sampel semakin banyak dan memenuhi jumlah sampel yang diinginkan ${ }^{9}$.

\section{HASIL DAN PEMBAHASAN}

\section{Hasil}

\section{a. Karakteristik subyek penelitian}

1. Berdasarkan kelompok umur

Responden paling banyak dalam penelitian ini adalah responden yang memiliki rentang usia 19-28 tahun sebanyak 43,34\%, dan paling sedikit pada rentang usia 59-68 tahun sebanyak 3,33\%. 
Tabel 1.Distribusi Karakteristik Responden Berdasarkan Umur

\begin{tabular}{cccc}
\hline No & Umur (Tahun) & Jumlah & Persentase $(\%)$ \\
\hline 1 & $19-28$ & 13 & 43,34 \\
2 & $29-38$ & 3 & 10 \\
3 & $39-48$ & 4 & 13,33 \\
4 & $49-58$ & 4 & 13,33 \\
5 & $59-68$ & 1 & 3,33 \\
6 & $69-78$ & 5 & 16,67 \\
\hline & Total & 30 & 100 \\
\hline
\end{tabular}

2. Berdasarkan frekuensi konsumsi

Persentase paling banyak didapatkan minuman keras pada responden yang mengkonsumsi

Persentase responden paling banyak minuman keras dengan jangka waktu 1-5 yaitu mengkonsumsi minuman keras 1 kali seminggu yaitu 33\%, sedangkan paling sedikit yang mengkonsumsi 6 kali seminggu tahun sebanyak $63,33 \%$ dan persentase paling sedikit didapatkan pada jangka waktu $>15$ Tahun yaitu $3,34 \%$. yaitu $3 \%$.

Tabel 2. Distribusi Karakteristik Responden Berdasarkan Frekuensi Konsumsi Minuman Keras

\begin{tabular}{cccc}
\hline No & Frekuensi Konsumsi & Jumlah & Persentase (\%) \\
\hline 1 & 1 Kali Seminggu & 10 & 33 \\
2 & 2 Kali Seminggu & 7 & 23 \\
3 & 3 Kali Seminggu & 5 & 17 \\
4 & 4 Kali Seminggu & 2 & 7 \\
5 & 5 Kali Seminggu & 3 & 10 \\
6 & 6 Kali seminggu & 1 & 3 \\
7 & 7 Kali Seminggu & 2 & 7 \\
\hline
\end{tabular}

3. Berdasarkan jangka waktu konsumsi

4. Berdasarkan volume konsumsi minuman minuman keras.

$$
\text { Responden paling banyak }
$$

mengkonsumsi 1,5 liter minuman keras 
yaitu sebesar $67 \%$ dan untuk konsumsi paling sedikit responden yaitu 2 liter minuman keras dengan persentase $10 \%$.
1. Hasil pengukuran kadar SGPT responden berdasarkan kelompok umur.

Responden pecandu minuman keras

Tabel 3. Distribusi Karakteristik Responden Berdasarkan Jangka Waktu Konsumsi Minuman Keras

\begin{tabular}{cccc}
\hline No & $\begin{array}{c}\text { Jangka Waktu Konsumsi } \\
\text { (Tahun) }\end{array}$ & Jumlah & Persentase (\%) \\
\hline 1 & 1-5 Tahun & 19 & 63,33 \\
2 & 6-10 Tahun & 4 & 13,33 \\
3 & 11-15 Tahun & 6 & 20 \\
4 & $>15$ Tahun & 1 & 3,34 \\
\hline & Total & 30 & 100 \\
\hline
\end{tabular}

5. Berdasarkan jenis minuman keras

Responden penelitian paling banyak mengkonsumsi minuman keras jenis tuak yaitu sebesar 47\%, sedangkan jumlah konsumsi paling sedikit yaitu minuman keras jenis arak dengan persentase $10 \%$. di Banjar Ambengan, Desa Sayan, Kecamatan Ubud, Kabupaten Gianyar, yang memiliki kadar SGPT normal paling banyak terdapat pada rentang usia 19-28 tahun sebanyak 54,2\%. Kadar SGPT tinggi paling banyak terdapat pada pecandu

Tabel 4.Distribusi Karakteristik Responden Berdasarkan Volume Konsumsi Minuman Keras

\begin{tabular}{|c|c|c|c|}
\hline No & Volume Konsumsi (Liter) & Jumlah & Persentase $(\%)$ \\
\hline 1 & 1 Liter & 7 & 23 \\
\hline 2 & 1,5 Liter & 20 & 67 \\
\hline 3 & 2 Liter & 3 & 10 \\
\hline \multicolumn{2}{|r|}{ Total } & 30 & 100 \\
\hline
\end{tabular}

b. Hasil pengukuran terhadap subyek penelitian berdasarkan variable penelitian dengan rentang usia 39-48 tahun sebanyak $33,3 \%$, rentang usia 49-58 tahun sebanyak 
33,3\% dan rentang usia 69-78 tahun 41,6\% dan responden yang mengkonsumsi 5 sebanyak $33,3 \%$. kali seminggu memiliki kadar SGPT yang tinggi terbanyak yaitu 33,3\%.

Tabel 5.Distribusi Karakteristik Responden Berdasarkan Jenis Minuman Keras

\begin{tabular}{cccc}
\hline No & Jenis Minuman Keras & Jumlah & Persentase (\%) \\
\hline 1 & Bir & 13 & 43 \\
2 & Tuak & 14 & 47 \\
3 & Arak & 3 & 10 \\
\hline & Total & 30 & 100
\end{tabular}

2. Hasil pengukuran kadar SGPT

3. Hasil pengukuran kadar SGPT responden responden berdasarkan frekuensi konsumsi minuman keras berdasarkan jangka waktu konsumsi Responden yang memiliki kadar SGPT Tabel 6. Kadar SGPT Responden Berdasarkan Kelompok Umur

\begin{tabular}{ccccc}
\hline Umur & \multicolumn{2}{c}{ Pecandu } & \\
(Tahun) & Normal & & Tinggi \\
& Jumlah & $\%$ & Jumlah & $\%$ \\
\hline $19-28$ & 13 & 54,2 & 0 & 0 \\
$29-38$ & 3 & 12,5 & 0 & 0 \\
$39-48$ & 2 & 8,3 & 2 & 33,3 \\
$49-58$ & 2 & 8,3 & 2 & 33,3 \\
$59-68$ & 1 & 4,2 & 0 & 0 \\
$69-78$ & 3 & 12,5 & 2 & 33,3 \\
\hline Total & 24 & 100 & 6 & 100 \\
\hline
\end{tabular}

Responden pecandu minuman keras di Banjar Ambengan, Desa Sayan, Kecamatan Ubud, Kabupaten Gianyar, yang memiliki kadar SGPT normal lebih banyak terdapat pada pecandu yang mengkonsumsi minuman keras 1 kali seminggu sebanyak normal paling banyak terdapat pada pecandu yang mengkonsumsi minuman keras dengan jangka waktu 1-5 tahun sebanyak 75\% dan kadar SGPT yang tinggi paling banyak terdapat pada pecandu yang mengkonsumsi 
minuman keras dengan jangka waktu 11-15 1,5 Liter dalam 1 kali kegiatan minum tahun sebanyak $50 \%$. sebanyak 66,7\% dan kadar SGPT lebih dari

4. Hasil pengukuran kadar SGPT normal paling banyak juga terdapat pada responden berdasarkan volume pecandu yang mengkonsumsi minuman konsumsi keras 1,5 liter dalam 1 kali kegiatan minum

Tabel 7. Kadar SGPT Responden Berdasarkan Frekuensi Konsumsi Minuman Keras

\begin{tabular}{ccccc}
\hline \multirow{2}{*}{$\begin{array}{c}\text { Frekuensi Konsumsi } \\
\text { (Per-Minggu) }\end{array}$} & Jumlah & $\%$ & Jumlah & $\%$ \\
\hline 1 Kali Seminggu & 10 & 41,6 & 0 & 0 \\
2 Kali Seminggu & 7 & 29,2 & 0 & 0 \\
3 Kali Seminggu & 4 & 16,6 & 1 & 16,7 \\
4 Kali Seminggu & 1 & 4,2 & 1 & 16,7 \\
5 Kali Seminggu & 1 & 4,2 & 2 & 33,3 \\
6 Kali seminggu & 0 & 0 & 1 & 16,7 \\
7 Kali Seminggu & 1 & 4,2 & 1 & 16,7 \\
\hline Total & 24 & 100 & 6 & 100 \\
\hline
\end{tabular}

Responden pecandu minuman keras yang memiliki kadar SGPT normal paling banyak yaitu yang mengkonsumsi minuman keras sebanyak $66,7 \%$.

5. Hasil pengukuran kadar SGPT responden berdasarkan jenis minuman

Tabel 8.Kadar SGPT Responden Berdasarkan Jangka Waktu Konsumsi

\begin{tabular}{ccccc}
\hline Jangka Waktu & \multicolumn{2}{c}{ Normal } & \multicolumn{2}{c}{ Tecandu } \\
Konsumsi (Tahun) & Jumlah & $\%$ & Jumlah & $\%$ \\
\hline 1-5 Tahun & 18 & 75 & 1 & 16,7 \\
6-10 Tahun & 3 & 12,5 & 1 & 16,7 \\
11-15 Tahun & 3 & 12,5 & 3 & 50 \\
$<15$ Tahun & 0 & 0 & 1 & 16,7 \\
\hline Total & 24 & 100 & 6 & 100
\end{tabular}


keras yang dikonsumsi

Responden pecandu minuman keras yang memiliki kadar SGPT normal paling banyak yaitu yang mengkonsumsi minuman faktor penyebab penyalahgunaan alkohol adalah faktor keturunan, pengaruh keluarga, aspek-aspek tertentu dalam hubungan dengan teman sebaya, etnis, karakteristik

Tabel 9. Kadar SGPT Responden Berdasarkan Volume Konsumsi

\begin{tabular}{ccccc}
\hline $\begin{array}{c}\text { Volume } \\
\text { Konsumsi } \\
\text { (Liter) }\end{array}$ & Normal & & \multicolumn{2}{c}{ Tecandu } \\
& Jumlah & $\%$ & Jumlah & $\%$ \\
\hline 1 Liter & 6 & 25 & 1 & 16,7 \\
1,5 Liter & 16 & 66,7 & 4 & 66,7 \\
2 Liter & 2 & 8,3 & 1 & 16,7 \\
\hline Total & 24 & 100 & 6 & 100 \\
\hline
\end{tabular}

keras jenis bir sebanyak $50 \%$ dan kadar SGPT yang tinggi paling banyak ditemukan pada responden yang mengkonsumsi minuman keras jenis tuak sebanyak $66,7 \%$. kepribadian, faktor genetik dan lingkungan sama-sama berperan ${ }^{10}$. Responden yang berusia diatas 30 tahun rata-rata sudah mengkonsumsi minuman keras dengan

Tabel 10. Kadar SGPT Responden Berdasarkan Jenis Minuman Keras Yang Dikonsumsi

\begin{tabular}{ccccc}
\hline & \multicolumn{4}{c}{ Pecandu } \\
\cline { 2 - 5 } Jenis Minuman Keras & \multicolumn{2}{c}{ Normal } & \multicolumn{2}{c}{ Tinggi } \\
& Jumlah & $\%$ & Jumlah & $\%$ \\
\hline Bir & 12 & 50 & 1 & 16,7 \\
Tuak & 10 & 41,7 & 4 & 66,7 \\
Arak & 2 & 8,3 & 1 & 16,7 \\
\hline Total & 24 & 100 & 6 & 100 \\
\hline
\end{tabular}

\section{Pembahasan}

Banyak faktor yang mempengaruhi seseorang sehingga memilih untuk mengkonsumsi minuman keras. Beberapa akhirnya menimbulkan berbagai penyakit hati seperti sirosis hati ${ }^{11}$. Sedangkan kadar SGPT yang normal paling banyak pada responden yang mengkonsumsi minuman 
keras 1 kali seminggu sebanyak 10 orang $(41,6 \%)$. Berdasarkan pengukuran yang dilakukan terhadap kadar SGPT pecandu, kadar SGPT normal paling banyak pada responden yang mengkonsumsi minuman keras 1,5 liter dalam 1 kali kegiatan minum sebanyak 16 orang $(66,7 \%)$ dan kadar SGPT lebih dari normal paling banyak juga terdapat pada pecandu yang mengkonsumsi minuman keras 1,5 liter dalam 1 kali kegiatan minum sebanyak 4 orang $(66,7 \%)$. Dijelaskan bahwa mengkonsumsi alkohol dengan volume berlebih akan menyebabkan kerusakan hepatosit yang disebabkan oleh toksisitas produk akhir metabolisme alkohol seperti asetaldehida dan ion hydrogen ${ }^{12}$. Ada 3 golongan minuman keras beralkohol, yaitu golongan A dengan kadar etanol $1-5 \%$ seperti bir, golongan B dengan kadar etanol 5-20\% seperti anggur, wine dan tuak, serta golongan C dengan kadar etanol 20-50\% seperti whiskey, vodka, mansonhouse, johnywalker, kemput dan arak. Semua golongan minuman keras dapat mengganggu kesehatan apabila dikonsumsi dalam jumlah yang berlebihan. Dijelaskan pula bahwa mengkonsumsi tuak yang termasuk minuman keras golongan B dan arak yang termasuk minuman keras golongan $\mathrm{C}$ dapat menyebabkan penyakit hati kronis seperti sirosis hati yang dapat meningkatkan kadar SGPT pada serum ${ }^{13}$

\section{SIMPULAN DAN SARAN}

\section{Simpulan}

Simpulan dari penelitian ini adalah hasil pemeriksaan kadar SGPT serum pecandu minuman keras berkisar antara 11-79,20 U/L. Berdasarkan nilai normal SGPT orang dewasa bahawa kadar SGPT para pecandu minuman keras di Banjar Ambengan Desa Sayan Kecamatan Ubud Kabupaten Gianyar yaitu dari 30 orang responden, 20\% reponden memiliki kadar SGPT yang tinggi yaitu sebanyak 6 orang dan $80 \%$ responden memilik kadar SGPT yang normal yaitu sebanyak 24 orang.

\section{Saran}

Bagi masyarakat Banjar Ambengan, Desa Sayan, Kecamatan Ubud, Kabupaten Gianyar khususnya pecandu minuman keras sebaiknya mengurangi minum minuman keras agar kadar SGPT nya tidak meningkattentang. Bagi peneliti selanjutnya, hasil penelitian ini digunakan sebagai acuan juga menambah karakteristik penelitian seperti tingkat pendidikan,

\section{DAFTAR PUSTAKA}

1. Fauziyah, A.H., 2015, Uji Aktivitas Hepatoprotektif Ekstrak Air Sarang Burung Walet Putif (Collocalia Fuciphaga Thunberg) Terhadap Aktivitas SGPT dan SGOT Pada Tikus 
Putih Janta Galur Sprague Dawley, Online,

http://repository.uinjkt.ac.id/dspace/bits tream/123456789/29062/1/AGENG\%2 0HASNA\%20FAUZIYAH-FKIK.pdf

diakses tanggal 12 Januari 2016

2. Conreng, D., B.J., Waleleng, dan S., Palar, 2014, Hubungan Konsumsi Alkohol Dengan Gangguan Fungsi Hati Pada Subjek Pria Dewasa Muda Di Kelurahan Tateli Dan Teling Atas Manado, Online, http://download.portalgaruda.org/article . php?article $=172333 \&$ val $=1001 \&$ title $=$ diakses tanggal 5 Januari 2016

3. Herlida, 2015, Hubungan Skor Apri (Aspartat Aminotransferase To Platelet Ratio Index) Dengan Derajat Keparahan Sirosis Hati Di Rsud Dokter Soedarso Pontianak, Online, http://jurnal.untan.ac.id/index.php/jfk/ar ticle/download /10593/10161 diakses tanggal 4 Januari 2016

4. Ronika, C., 2012,Peningkatan Kadar Serum Glutamic Piruvic Transaminase (Sgpt) Pada Tikus Wistar (Rattus Norvegicus) Jantan Yang Dipapar Stresor Rasa Sakit Renjatan Listrik, Online,

http://repository.unej.ac.id/bitstream/ha $\underline{\text { ndle/123456789/3360/Skripsi.pdf?sequ }}$

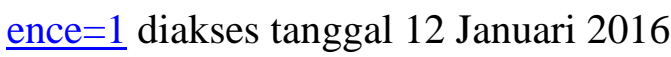

5. Suaniti, dkk., 2012, Kerusakan Hati Akibat Keracunan Alkohol Berulang pada Tikus Wistar, Online, http://download.portalgaruda.org/article . php? article $=82935 \&$ val $=972$ diakses tanggal 10 Januari 2016

6. Indraprasti, D., dan M.A., Rachmawati, 2008, Hubungan Antara Kontrol Diri Dengan Perilaku Minum-Minuman Keras Pada Remaja Laki-Laki, Online, http://pository.uii.ac.id/320/SK/I/0/00/0 00/000784/uii-skripsi-psikologi

kesehatan - kecanduan-indraprasti $\underline{\text { 04320092-4912848072-naskah }}$

publikasi.pdf diakses tanggal 4 Januari 2016

7. Suryadarma, I.G.A., dan P.M.A., Saskara,2012, Laporan Kasus Sirosis Hepatitis, Online, http://download.portalgaruda.org/article . php article $=82524 \quad$ val $=970$ diakses tanggal 4 Januari 2016

8. Notoatmodjo, S., 2012, Metodologi Penelitian Kesehatan, Edisi Revisi Cetakan Kedua,Jakarta: PT RINEKA CIPTA

9. Sugiyono, 2013, Statistika Untuk Penelitian, Cetakan ke-23, Bandung : Alfabeta

10. Sulistyowati, D., 2012, Hubungan Tingkat Pengetahuan Dan Sikap Remaja Usia Pertengahan Tentang 
Bahaya Minuman Keras Dengan

Perilaku Minum- Minuman Keras Di

Desa Klumprit Sukoharjo, Online.

http://NASKAH_PUBLIKASI_DESI

OKE.pdf diakses tanggal 24 Juni 2016

11. Hernawati, 2009, Gambaran Efek Toksik

Etanol Pada Sel Hati, Online, http://dokumen.tips/documents/file-15-

5590a46c1de2b.html diakses tanggal 12 Januari 2012

12. Agustin, D., 2013, Analisis Praktik Klinik Keperawatan Kesehatan Masyarakat Perkotaan Pada Pasien Dengan Sirosis Hepatis Di Ruang Pu 6 Rumah Sakit Pusat Angkatan Darat Gatot Soebroto Jakarta Pusat, Online, http://digital_20351501-PR-Destiana Agustin.pdf diakses pada tanggal 22 Juni 2016

13. Panggabean, S.M., 2015, Analisis Konsumsi Tuak Pada Peminum Tuak Di Desa Lumban Siagian Jae Kecamatan Siatas Barita Kabupaten Tapanuli Utara Sumatera Utara Tahun 2015, Online, http://repository.uinjkt.ac.id/dspace/ bitstream/123456789/29599/3/SUKMA \%20MARDIYAH\%20PANGABEAN-

FKIK.pdf diakses pada 22 Juni 2016 
